\title{
ENTREPRENEURSHIP EDUCATION OF COMMUNITIY EMPOWERMENT IN BUKIT BARISAN SELATAN NATIONAL PARK: A Case Study in Kubu Perahu Village West Lampung
}

\author{
May Roni \\ Faculty of Social and Politic Sciences Lampung University \\ publicspace.roni@gmail.com
}

\begin{abstract}
This study aims to find out the process and result of entrepreneurship education of community empowerment in Kubu Perahu Village. This is a kind of descriptivequalitative research focusing on the processes described in four dimensions, namely: Access to Information, Inclusion \& Participation, Accountability and Local Organization Capacity and the results divided into two indicators, namely: Indirect Indicator of Empowerment and Direct Indicator of Empowerment. The result of the research shows that the process of educational empowerment in Community entrepreneurship carried out by the BBSNP Center and the Kubu Perahu Village community has still not yet optimal. In addition the results of educational empowerment of entrepreneurship in the community in Kubu Perahu Village that have not achieved success. Community empowerment and community welfare are still not felt as a whole. The need for improvement of cooperation between the Balai Besar TNBBS and the Kubu Perahu Village Community in relation to education empowerment community entrepreneurship is mainly required. The community must also think critically, creatively and innovatively in utilizing the potencies and opportunities related to community entrepreneurship empowerment.
\end{abstract}

Keywords: Community Empowerment, Entrepreneurship, Process and Results

\section{INTRODUCTION}

Based on Law No. 10 of 2009 concerning Tourism, it is explained that tourism development is needed to encourage equal opportunities for business and benefit and able to face the challenges of changes in local, national and global life. Optimal tourism development will be able to improve economic growth and people's welfare. Therefore tourism objects must be managed properly. Good and planned tourism management will have a positive impact on the economy, social and culture.

Referring to the national tourism development master plan, the Lampung Provincial Government has made Regional Regulation No.6 of 2012 concerning the 
Regional Tourism Development Master Plan (RIPPDA). As of 2014, it has determined seven Strategic Tourism Regions, namely Bandarlampung, Krui and Tanjung Setia, Way Kambas National Park, Kiluan Bay, Krakatau Mountain and Sebesi Island, Bakauheni and Siger Towers, and Bukit Barisan Selatan National Park. Whereas in Lampung there are three tourism objects that have been designated as National Tourism Strategic Areas (KSPN) namely Lake Ranau, Way Kambas and Krakatau.

Lampung Province has 15 (fifteen) regencies / cities, one of which is West Lampung Regency. Topographically West Lampung is divided into two, hilly areas with an altitude of 600 to $1000 \mathrm{~m}$ above sea level, covering the districts of Balik Bukit and Sumber Jaya, mountainous areas with altitudes of 1000 to $2000 \mathrm{~m}$ above sea level covering most of Belalau, Sekincau and other sub-districts which are all clusters of Bukit Barisan. Most of the West Lampung region is sloping to very steep slopes of $70 \%$ of the entire region and is equipped with the beauty of tropical rainforests that are still awake and beautiful panoramic views of the mountains (Youth Service of Tourism and Culture of West Lampung).

The followings are some excellent tourism objects in West Lampung Regency which have been well managed by the travel agencies or by the local community.

Table 1.

Top Tourism Objects in West Lampung Regency

\begin{tabular}{|l|l|l|}
\hline No. & \multicolumn{1}{|c|}{ Tourism site } & \multicolumn{1}{c|}{ Location } \\
\hline 1. & Rest Area Sumber Jaya & $\begin{array}{l}\text { Pekon Sindang Pagar, Kec. Sumber } \\
\text { Jaya }\end{array}$ \\
\hline 2. & Way Besai Rafting & Suka Jaya Pekon, Kec. Sumber Jaya \\
\hline 3. & $\begin{array}{l}\text { Lake Ranau, Seminung Lumbok } \\
\text { Resort and Tourism Village }\end{array}$ & Kec. Lumbok Seminung \\
\hline 4 & Bukit Barisan Selatan National Park & Pekon Kubu Perahu, Kec. Balik Bukit \\
\hline 5. & Mount Pesagi Religious Tourism & Kec. Balik Bukit \\
\hline 6. & Archaeological Site of Batu Brak & Pekon Pura Jaya, Kec, Kebun Tebu \\
\hline 7. & Lake Suoh & Kec. Suoh \\
\hline \multicolumn{2}{|c|}{ Source: West Lampung Tourism and Culture Sports Youth Service. }
\end{tabular}

Source: West Lampung Tourism and Culture Sports Youth Service.

West Lampung Regency is very lucky because Bukit Barisan Selatan National Park (TNBBS) is included in the administrative area of this district. BBSNP is the 3rd largest national park area in Sumatra Island with an area of 356,800 hectares, stretching from the southern tip of the western Lampung Province to the southern part of the Bengkulu Province. Seventy percent of BBSNP is included in the Regency administration West Lampung and Regency area Tanggamus, where both are part of the Province Lampung. Other parts of BBSNP are in the Kaur region of the Province Bengkulu . South Sumatra it is also very important for overlapping the borders of BBSNP with the provincial 
border. TNBBS itself has been established by UNESCO as a world heritage because it has biodiversity both in terms of forests, flora and fauna and as the oxygen producer that the world needs. BBSNP in the West Lampung area is currently in the management of the National Park Management Area (BPTN) II Liwa. Tourism objects in BBSNP offer tourism activities, among others, camping, forest exploration, mountain climbing, wildlife observation, white water rafting, canopy trail, outbond training, commercial film snapshoots and regional research activities (quoted from www.tnbbs.org).

Based on information compiled from the source website www.tnbbs.org, the management of the National Park area began to experience a shift from the pattern of strengthening protection to the maximum utilization pattern for the welfare of the community. Therefore, the involvement and participation of the community in the management of BBSNP is absolutely necessary. To reach the target, increasing the welfare and coaching of the surrounding community is the key to its success. The development of entrepreneurs in the form of a model conservation villages that have been developed in previous years needs to be improved and in the evaluation of its success. In addition, the pattern of partnerships and assistance to surrounding villages as a buffer for BBSNP areas continues to be developed. Increasing welfare and public awareness of the importance of BBSNP areas is the expected outcome, so that in the future the management of BBSNP will be in line with the welfare of the community.

After the enactment of the BBSNP area as the utilization of the welfare of the surrounding community, there is a buffer village which is used as a model for conservation villages. Kubu Perahu Village is one of the conservation village models. Judging from the geographical conditions, the village of Kubu Perahu is in the TNBBS area and access to the village is very easy because it is in the Liwa-Krui crossing. Kubu Perahu Village is also one of the tourist gates to the BBSNP and its location is very strategic and has beautiful natural scenery. Utilizing the village model of conservation of BBSNP tourism objects, the village of Kubu Perahu is still not optimal in improving the economy of the surrounding communities. This is due to the lack of enthusiasm and community involvement related to the use of tourism objects. Kubu Perahu village is still very new as a tourist conservation village, this also underlies the number of tourist visits is still very low to visit the village. Generally tourists only cross the village, because Kubu Perahu village is still not maximal in an effort to become a tourist conservation village.

Based on the background described above, formulation of the problem of the research is: How to empower education of entrepreneurship to the local community around the Bukit Barisan Selatan National Park, West Lampung Regency?

\section{LIERATURE REVIEW}

Before elaborating further about community empowerment, the first to be reviewed is about the definition of community empowerment. Definitions related to 
community empowerment have been described by experts. Of the various definitions that exist, in broad outline implies that community empowerment is an increase or the ability of people or groups weak related to access to information to resources, participation or involvement in development, holding accountability parties that affect their lives, and the ability to make decisions with duku with local institutions (Bhimo, 2012).

It was concluded that community empowerment is an increase in the ability of vulnerable and weak people or groups, to have access to information on resources, participate or involvement in development, hold the parties accountable for their lives, and the ability to make decisions with institutional support local (Bhimo, 2012).

Another term that often follows empowerment is community empowerment. According to Wrihatlono and Dwidjowijoto (2007) in Bhimo (2012), community empowerment is an element that allows people to survive and be dynamic in developing themselves and achieving progress. Community empowerment is a source of political insight at the national level called national resilience. In line with this definition, Mardikanto (2010: 22), defining empowerment in the context of society is the ability of individuals to mix with the community and build the empowerment of the community in question. A society where most of its members are physically and mentally healthy, educated and strong, of course has high empowerment.

In community empowerment, there are various variables, factors, aspects, or elements that synergize with each other. The following is a model of community empowerment according to Ruth Alsop, Mette Frost, and Jeremy Holland (2006: 10), empowering as a capacity of individuals or groups to make effective choices, influenced by two factors, namely: Agency and Opportunity Structure.

1) Agency

Agency is defined as an actor or group that has the ability to make choices. The actor is able to imagine and choose choices according to the goals they want to achieve. In terms of measurement and action to increase empowerment, the agency's ability of a person or group can be estimated through the contribution of their assets (asset endowment). According to Moser and Swift (Alsop, et al. 2006: 10), assets are a stock of resources that complement actors to use economic, social and political opportunities, to be productive, and to protect themselves from shocks. Assets require measurement for monitoring or analysis or consideration in operational work, including: psychological assets, information, organization, material, social, financial and human. 


\section{2) Opportunity Structure}

An actor may be able to choose choices, but the effective realization of their choices will depend largely on the institutional context in which the actor lives and works. Opportunity Structure consists of institutions that govern people's behavior and influence the success or failure of the choices they make.

The explanation shows the relationship between Agency and Opportunity Structure. The Agency cannot be treated as the only one who is identical in empowerment. In fact, when people have the ability to choose choices, they may not be able to use effective institutions, because they are constrained by opportunity structures, which are defined as aspects of the institutional context, which affect their ability to transform into action by forming "rules of the games" in agency implementation, for a level greater or smaller than effectiveness (Bhimo, 2012: 24).

This rule can also affect the increase in the inventory of assets and determine the value of benefits that flow from the asset. These factors together give rise to different degrees of empowerment and are assumed to have strengthened their influence on development outcomes. The figure below shows that Agnecy and Opportunity Structure are associated with the degree of empowerment experience of a person or group. This also shows the relationship between empowerment and development outcomes.

\section{RESEARCH METHODS}

This research is a descriptive study with a qualitative approach. Bogdan and Taylor in Moleong (2007) define qualitative research as a research procedure that produces descriptive data in the form of written or verbal words from people and observed behavior of the phenomena that occur . Moleong (2007) further stated that descriptive research emphasizes on data in the form of words, pictures, and not numbers caused by the application of qualitative methods. In addition, all that is collected is likely to be the key to what has been studied. The results of this study only describe or construct in-depth interviews of research subjects so that they can provide a clear picture of entrepreneurship education in the community around the attractions of Bukit Barisan Selatan National Park in the West Lampung Regency.

The research location is a place where the researcher conducted research, especially in capturing actual phenomena or events that occur from the object under study in order to obtain accurate research data. In determining the location of the study, Moleong (2007: 132) determines the best way to be taken by considering the 
substantive theory and exploring the field and finding conformity with the reality in the field. While geographic and practical limitations such as time, cost, energy need to be taken into consideration in determining the location of the study. The location of this research is Kubu Perahu Village, West Lampung Regency. The location was taken intentionally and based on the following considerations:

1. National park management began to experience a shift from a pattern of strengthening protection to the maximum utilization pattern for the welfare of the community. Development of economic enterprises in the form of conservation village models.

2. TNBBS is the 3rd largest national park on the island of Sumatra and is included in the strategic tourism area.

3. Enter the tourism area of BBSNP.

4. It is a conservation village for BBSNP tourism.

5. As a place for one of the access points of the TNBBS tourism object.

Research subjects or someone who provided information related to the title of the study were the entrepreneurial education of the community around the park's tourism object. Someone who provided the information was also called an informant. Informants are people who are expected to provide information about the situation and conditions (Sugiyono, 2009: 208). Do not use the term population in qualitative research, but rather a social situation or social situation consisting of three elements, namely, place ( place), actor ( actor), and activity (activity). The social situation can be expressed as an object of research that wants to know what is happening in it.

Processing and data analysis using descriptive analysis were carried out to identify entrepreneurship education in the communities around the tourism objects in the TNBBS area. West Lampung. Descriptive research is research based on descriptive data from the status, circumstances, attitudes, relationships or systems of thought of a problem that is the object of research. After obtaining the data obtained in this study, the next step is to process the collected data by analyzing data, describing the data, and drawing conclusions. To analyze this data using qualitative data analysis techniques, because the data obtained is a collection of information. The data analysis process begins by preparing all available data from various sources, namely through observation, interviews, and documentation.

\section{DISCUSSION \\ General Description}

Bukit Barisan Selatan National Park (TNBBS) is the 3rd largest national park area on the island of Sumatra. The BBSNP area covers an area of $\pm 355,511$ $\mathrm{Ha}$, stretching from the southern western tip of Lampung Province to the southern part of Bengkulu Province. Geographically located at $4^{\circ} 29^{\prime}-5^{\circ} 57$ 'LS and 103 $24^{\prime}$ $104^{\circ} 44^{\prime} \mathrm{BT}$. According to government administration, the area of BBSNP is included in the area of Tanggamus Regency, West Lampung Regency and Pesisir Barat Regency Lampung Province covering $\pm 280,300 \mathrm{Ha}$ and Kaur Regency, Bengkulu 
Province covering $\pm 64,711 \mathrm{Ha}$. While the central part to the north east of BBSNP is adjacent to Ogan Komering Ulu Regency, South Sumatra Province. The basis for the management of BBSNP has been clearly printed in the history of law and government policy. Not only the central government and local governments that have recognized the management of this region, even the international community has designated it as a world heritage.

Once upon a time the Boat was a public stopover from Liwa to Krui and vice versa. Kubu Perahu is located within the BBSNP and is an enclave land. Enclave is the pockets of traditional community settlements in the forest that have been going on for generations. So that the boundary around Kubu Perahu is the Bukit Barisan Selatan National Park. Boat Area \pm 100 Ha. The population of Kubu Perahu is \pm 380 people with 215 men and 165 women, the average level of education of the people there is elementary school graduates. The village of Kubu Perahu has actually been expanded to the border of the City of Liwa, but the original area which is in direct contact with the park's tourism objects is in Pemangku I in the enclave.

A very interesting object for visitors in the location of Kubu Perahu is the observation of the Sumatran tokhtor ( Carpococcyx viridis ) which is an endemic bird and belongs to the rare category. For visitors who do not have a long time, do outbonds above the Way Sindailapai river and around the campground Kubu Perahu can be an attractive choice for ecotourism in this area. Exploring mountain tropical rain forest as a habitat for various types of forest orchids to get to the Sepapa Kanan and Sepapa Kiri waterfalls to be another type of activity that can be done. Can also stay on the campground for camping or at thehomestay of residents in the Kubu Perahu enclave. Access to the village of Kubu Perahu transportation can use public transport such as buses or private vehicles d ari Bandar Lampung - Kotabumi - Bukit Kemuning - Liwa - TNBBS (Kubuperahu) $\pm 246 \mathrm{~km}$, can be reached by four-wheel vehicles for \pm 6 hours.

\section{Community Empowerment Results in Kubu Perahu Village}

1. Psychological Assets

The results of community empowerment in the village of Kubu boat on psychological assets that are ready. The community has begun to realize to develop the community's economy by entrepreneurship. Entrepreneurship is done in groups and individuals. In groups by creating business groups namely the Lestari Sejahtera business group, the Bamboo Craft Group and the Hydro Micro Group. The Lestari Sejahtera group is engaged in homestay accommodation services by renting residents' homes that are members of groups to become a place for lodging for foreign and local tourists. In addition, the Lestari Sejahtera Group also created village unit cooperatives for the people of Kubu Perahu Village. Bamboo Craft Group is a form of people's creativity by processing bamboo into chairs, tables and other accessories. The bamboo material is obtained from bamboo in the edge of the Sindailapai river and from outside the village. In addition to cultivating the community, they also do bamboo rejuvenation by replanting bamboo along 
the river so that the bamboo can be useful again and does not damage the environment. The Hydro Micro Group is the management of small-scale electricity generation made by the citizens initiated by the BBBBS Center. Its function is to supply electricity to people's homes with very affordable fees. Whereas entrepreneurship individually there are people who process soybeans into tempeh, tofu, oncom and gembung, then there are also those who open small shops and small restaurants as places to stop.

2. Information Assets

The results of community entrepreneurship education in the village of Kubu Perahu on information assets are still not optimal. In Kubu Perahu it is very difficult to signal a cellular operator, just to make a call, you have to go out of the house or look for a place to make it clear, whereas in sending a cellphone, there is a dispatch.

3. Organizational Assets

The results of community empowerment in the village of Kubu Perahu on organizational assets are good enough. The community has played a role in the formation of business groups and running them. The business group that the community made was initiated by the BBBBS Center, meaning that the community has utilized the opportunity to take advantage of the existing potential. The role of the community in the organization has also been good enough, such as giving opinions, solving problems in the organization and managing the organization. All things socialized by the Center for BBSNP related to the organization are well applied by the community, living in an innovative and creative way may be a factor that strongly supports the improvement of community entrepreneurship education .

4. Material Assets

The results of community entrepreneurship education in Kubu Perahu Village on material assets already exist. The land occupied by the community is enclave land that has become the property of the community. Based on the policy of the Balai Besar TNBBS regarding the transfer of functions from strengthening protection to the maximum utilization for the welfare of the community, it means that the community can access the BBSNP area to exploit the potential, but still protect the environment, the intention is not to damage the forest and hunt for animals in BBSNP. The possibility of entrepreneurship that can be done is tourism in the service sector and processing materials in enclave land. In fact, the community is still not free to access this. It can be concluded that community material assets already exist but are not optimal.

5. Financial Assets

The results of community entrepreneurship education in the village of Kubu boat on financial assets are sufficient. In conducting education empowerment entrepreneurship, the people of Kubu Perahu Village still collect capital independently. The community forms business groups with capital independently, while for entrepreneurship individually, capital is derived from public savings. The community still has 
not dared to get capital with credit, nor has it invested in capital from related institutions because the procedure is still not understood by the public.

\section{Human Resource Assets}

The results of community entrepreneurship education in Kubu Perahu village on human resource assets are sufficient. On average the people of Kubu Perahu have been literate because the community education background is at least elementary school graduates. In addition, the community is also open to knowledge, such as when there is socialization, the community is very enthusiastic in responding and exchanging ideas with tourists regarding scientific information. The impact is that the community has been able to carry out entrepreneurial processes such as running business groups from management to marketing products.

\section{Application of Rural Tourism in Kubu Perahu Village}

Rows of conflict cases that have always been a formidable challenge for the development of rural tourism can still be stretched. Although the interest of the local community to manage tourism physical resources is quite high, it is often not followed by adequate management capabilities. On the other hand, tourists also have great interest in enjoying as many tourism events as possible in the countryside, but there is not much time allocated for them. Problems also arise when tourists have arrived at the place but the public is not ready to show the event. Schedule of cultural performances is postponed, even though tourists only have limited time. Conflict is unavoidable because: first, tourists expect the show to be held on time as informed by the previous local guide; second, the traveler forward e vent even-specific starting and beginning to end, but was forced to be disappointed because the circuit must be terminated in the event the other day (Cole, 2006 in Damanik, 2013 : 4).

Based on the above explanation, if it is associated with the results of the study that Kubu Perahu Village has the characteristics of rural tourism prospects. Kubu Perahu village is located within the park and becomes the access point for tourists. Within the region there are types of tourism such as adventure tours in the forest, tourist attractions in the form of natural waterfalls, campgrounds with outbound facilities and rafting. However, the people of Kubu Perahu Village are not ready to participate in developing rural tourism. This is related to the constraints faced by the Kubu Perahu Village community, such as access to information related to the use of socialization or the process of obtaining funding resources that are still not optimal, lack of clarity in the policies of the TNBBS Central Office which is still overlapping. and the ability of the community today is still limited to running entrepreneurship that has not focused on rural tourism. For this reason, the welfare of the people with the application of rural tourism cannot be realized in Kubu Perahu Village to date.

\section{CONCLUSIONS AND RECOMMENDATIONS}


Based on the findings in the field and the results of discussions related to entrepreneurship education in the community in the village of Kubu it can be concluded, as follows:

1. TNBBS is the body that manages the BBSNP and all activities carried out by the community in BBSNP under the supervision of the Balai Besar. The Balai Besar TNBBS issued policies governing all matters in the BBSNP area. The village of Kubu Perahu stakeholder is an enclave land which means it is located within the BBSNP area. Second, the Village Community of Kubu Perahu Pemangku I. In this case the community is the core of the community empowerment activities. The community plays a role in making entrepreneurship by utilizing existing potential by doing individually or in groups

2. Opportunity Structure (opportunity structure), Head of Pemangku I Kubu Perahu Village as Opportunity Structure. This is because the village of Kubu Perahu has actually been expanded to the border of the City of Liwa, but the original area and in direct contact with the park's tourism objects are in Pemangku I in the enclave. Furthermore, in empowering the community in the village of Kubu Perahu because of cooperation between the Balai Besar TNBBS and the community, it was bridged by the Head of the Pemangku I as the leader or apartment in the area.

3. The process of entrepreneurship education community in the village of Kubu Perahu conducted TNBBS Great Hall and the village of Kubu Perahu community is still not yet optimal. Efforts of TNBBS in empowerment role the community to be in tune with the program still happens very slowly in capturing people's expectations. Whereas the Kubu Perahu community itself is actually ready to do an introduction entrepreneurship education. This can be an alternative to face this.

4 The Result of introduction Entrepreneurship education in the community in Kubu Perahu Village that has not yet achieved the success of community empowerment and welfare is still not there. This is because the influence of the empowerment process which is not optimal and from several indicators that exist on direct empowerment indicators and indirect empowerment indicators, have not been fulfilled in Kubu Perahu Village, besides that there are still those whose results have not yet affected the whole. Regarding the issue of rural tourism that currently the application of rural tourism cannot yet be realized in the area of Kubu Perahu.

\section{Suggestion}

In the future, it is expected that the Balai Besar TNBBS and the community of Kubu Perahu Village can work together even better regarding community empowerment through the path of entrepreneurship education. BBSNP's large centers need to improve the community empowerment process in Kubu Perahu Village optimally for the welfare of the community and the realization of the vision and mission of the BBBBS Center. The Kubu Perahu Village Community is expected to carry out community-friendly entrepreneurial education activities by 
utilizing the opportunities and potential that exist and can establish cooperation with parties other than the BBSNP Balai Besar to support community empowerment.

The community must also think critically, creatively and innovatively in utilizing the potencies and opportunities related to the empowerment of community entrepreneur interest. Kubu Perahu Village can be an area that has increased community empowerment and applies rural tourism such as, in villages around the area of Bromo Tengger Semeru National Park (TNBTS), Lembang area, Puncak Bogor area, tourism villages in Bali or Lombok and others who have entrepreneurial values.

\section{REFERENCES}

Alfitri. 2011. Community Development: Teori dan Aplikasi. Pustaka Pelajar. Yogyakarta.

Azizy, Ahmad Qodri A. 2003. Pemberdayaan Masyarakt dalam Pengembangan Kehidupan Berdemokrasi di Indonesia. Lembaga Executive Club (LEC) Press. Jakarta.

Bhimo, Johan Sukoco. 2012. Pemberdayaan Masyarakat dalam Program Perpustakaan Kelurahan di Kelurahan Panularan Kota Surakarta. Skripsi. Prodi Administrasi Negara. Fakultas Ilmu Sosial dan Ilmu Politik. Universitas Sebelas Maret. Surakarta.

Henny, Ni Luh Andayani. 2014. Manajemen Pemasaran Pariwisata. Penerbit Graha Ilmu. Yogyakarta.

Janianton, Phil. Damanik. 2013. Pariwisata Indonesia Antara Peluang dan Tantangan. Penerbit Pustaka Pelajar. Yogyakarta.

Karay, Jonathan Kosmus. 2012. Memberdayakan Ekonomi Kerakyatan Sektor Pariwisata di Papua. Jurnal. Universitas Sains dan Teknologi Jayapura. Jayapura.

Kusuma, Ika Purnama Sari. 2011. Pemberdayaan Masyarakat Melalui Desa Wisata dalam Usaha Peningkatan Kesejahteraan (Desa Candirejo, Magelang, Jawa Tengah). Jurnal. Universitas Indonesia. Jakarta.

Mardikanto, Totok. 2010. Konsep-konsep Pemberdayaan Masyarakat. Fakutas Pertanian UNS dengan UPT Penerbitan dan Percetakan UNS (UNS Press). Surakarta.

Moleong, L.J. 2007. Metodologi Penelitian Kualitatif. Remaja Rosadakarya. Bandung.

Mulyadi. 2012. Ekonomi Sumber Daya Manusia. PT. Rajagrafindo Persada. Jakarta.

Purnamasari, Andi Maya. 2011. Pengembangan Masyarakat Untuk Pariwisata Di Kampung Wisata Toddabojo Provinsi Sulawesi Selatan Jurnal. Institut Teknologi Bandung. Bandung.

Rohana, Emi. 2014. Pemberdayaan Ekonomi Masyarakat di Desa Tembi. Jurnal. Universitas Islam Negeri Sunan Kalijaga Yogyakarta. Yogyakarta.

Sugiyono. 2009. Metode Penelitian Bisnis. Penerbit Alfabeta. Bandung.

Sun'an, Muammil \& Abdurrahman Senuk. 2015. Ekonomi Pembangunan Daerah.

Penerbit Mitra Wacana Media. Jakarta. 
Suryadana, M. Liga \& Vanny Octavia. 2015. Pengantar Pemasaran Pariwisata. Penerbit Alfabeta. Bandung.

\author{
Website \\ http://www.harianlampung.com/m/index.php?ctn=1\&k=wawancara\&i=2287. \\ http://programs.wcs.org/btnbbs/Profile. \\ http://www.bps.go.id/Subjek/view/id/16\#subjekViewTab3. \\ http://lampung.bps.go.id/Subjek/view/id/16.
}

